\title{
Anti-Neospora caninum antibodies among dairy cattle in a rural settlement, Paraná, Brazil
}

\section{Prevalência de anticorpos anti-Neospora caninum em bovinos leiteiros de um assentamento rural, Paraná, Brazil}

\author{
Shiguedy Katto ${ }^{1}$; Luiz Fernando Coelho da Cunha Filho \\ Alexey Leon Gomel Bogado; ; Thais Agostinho Martins;3; Ana Sue Sammi; \\ Joeleni Rosa dos Santos ${ }^{3}$; Isabelli Sayuri Kono3; Mércia de Seixas; \\ Beatriz de Souza Lima Nino ${ }^{3}$; João Luis Garcia ${ }^{4 *}$
}

\begin{abstract}
The aim of the present study was to evaluate the seroprevalence of antibodies against Neospora caninum, obtained two years apart, among dairy cattle in a rural settlement in southern Brazil. Blood samples from 734 dairy cattle on 41 farms were collected at two different times: in 2012, 406 animals on 30 farms were used; and in 2014, 329 animals on 31 farms. Serum samples were obtained and were used to detect antibodies against $N$. caninum, by means of the indirect fluorescence assay (IFA). Animals with titers $\geq 100$ were considered positive. The total serum prevalence of anti- $N$. caninum antibodies was $19.7 \%$ (145/736) among all the dairy cattle, comprising $23.1 \%(94 / 406)$ in 2012 and $15.5 \%(51 / 329)$ in 2014. Serum from 91 animals was tested in both trials: 11(12.1\%) showed positivity in 2012 and $10(11 \%)$ in 2014. The variables of age, sex and breed did not show any associations with seropositivity. Thus, we showed that the cattle in this settlement presented high levels of antibodies against $N$. caninum, and that IFA showed good efficacy for epidemiological studies.
\end{abstract}

Key words: Neosporosis. Reproductive problems. Seropositive.

\section{Resumo}

O objetivo deste estudo foi avaliar a soroprevalência de anticorpos contra Neospora caninum em bovinos de leite de um assentamento rural, região sul do Brasil. Participaram do estudo um total de 734 bovinos de leite, 406 animais de 30 propriedades coletados em 2012, e 329 animais de 31 propriedades em 2014. Amostras de soro foram analisadas por meio da Reação de Imunofluorescência Indireta (RIFI), animais com títulos $\geq 100$ foram considerados positivos. A soroprevalência total para anticorpos contra $N$. caninum foi 19,7\% (145/736), 23,1\% (94/406) e 15,5\% (51/329) em 2012 e 2014, respectivamente. Noventa e um animais tiveram amostras analisadas em ambos estudos, $11(12,1 \%)$ evidenciaram positividade em 2012 e 10 (11\%) em 2014. Não houveram associações entre as variáveis estudadas (idade, sexo e raças) com a soropositividade para neosporose. Evidenciou-se com o presente estudo um alto nível de anticorpos contra $N$. caninum nos bovinos desse assentamento rural, bem como, a RIFI utilizada mostrou boa eficácia para estudos epidemiológicos.

Palavras-chave: Neosporose. Problemas reprodutivos. Soropositivo.

\footnotetext{
${ }^{1}$ Médico Veterinário, Instituto Paranaense de Assistência Técnica e Extensão Rural, EMATER, discente, Universidade Norte Paranaense, UNOPAR, Arapongas, PR, Brasil. E-mail: shiguedy@gmail.com

${ }^{2}$ Prof., Curso de Medicina Veterinária, UNOPAR, Arapongas, PR, Brasil. E-mail: luiz.cunha@unopar.br; alexey_leon@yahoo. com.br

3 Discentes, Laboratório de Protozoologia, Departamento de Medicina Veterinária Preventiva, Universidade Estadual de Londrina, UEL, Londrina, PR, Brasil. E-mail: alexey_leon@yahoo.com.br; thaismedvet620@gmail.com; a.sammi1103@gmail.com; joeleni_r@hotmail.com; isabelli.kono@gmail.com; mercia_seixas@yahoo.com.br; bianino@hotmail.com

4 Prof., Laboratório de Protozoologia, Departamento de Medicina Veterinária Preventiva, UEL, Londrina, PR, Brasil. E-mail: jlgarcia@uel.br

* Author for correspondence
} 


\section{Introduction}

Neospora caninum is a protozoan parasite with worldwide distribution, and it is an important abortifacient in cattle (DUBEY, 2005). Brazil is a country with approximately 205.3 million cattle, including both dairy and beef cattle (IBGE, 2012), and this is the biggest commercial herd worldwide (ANUALPEC, 2011). The great majority of the herds are raised on pasture with a production of around 9.3 million tons of meat and milk production of around 30 billion liters per year (ANUALPEC, 2011). Thus, considering all these data taken together and assuming that neosporosis causes both direct and indirect losses relating to cattle-rearing (DUBEY et al., 1999) this parasite can be considered to be one of the main agents responsible for economic losses among cattle in Brazil.

The first study on the epidemiology of neosporosis in dairy cattle in Brazil was conducted by Gondim et al. (1999). These authors conducted a seroprevalence study among lactating dairy cows in northeastern Brazil and described an overall prevalence of $14.09 \%(0-23.53 \%)$. Additionally, histopathology and immunohistochemistry were used to characterize $N$. caninum as an important abortifacient agent in cattle. Corbellini et al. (2002) correlated bovine abortion with $N$. caninum in southern Brazil.

The aim of the present study was to evaluate the seroprevalence of $N$. caninum among dairy cattle in a rural settlement located in southern Brazil, at two different times: the first in 2012 and the second in 2014.

\section{Materials and Methods}

\section{Study location}

The present study was conducted in a rural settlement located in the north of the state of Paraná. This settlement has an area of 756 hectares (ha), on which 93 families (369 people) had been settled on plots of 6.05 ha each, thus totaling 93 properties.
Cattle were reared on 56 of these farms. The cattle herd consisted of 1,009 head, with 277 dairy cows, 165 dry cows, 241 heifers, 170 calves up to one year of age, 70 steers, 61 calves and 25 bulls. The main management system for the cattle was semiextensive. The animals had access to rotational grazing, supplemented with bulk feed at critical times of the year and concentrated diet all year round. The storage facilities and supply of these foods provided access to dogs, rodents and other animals. The population of dogs was 254 animals.

The climate according to Köppen's classification is CFA, i.e. subtropical, characterized by average temperatures in the coldest months $<18{ }^{\circ} \mathrm{C}$ (mesothermal) and in the warmer months $>22$ ${ }^{\circ} \mathrm{C}$; hot summers, winters with infrequent frosts and a tendency for rainfall to be concentrated in the summer months, but without any dry season (RITTA NETO, 2010). The average rainfall is about $1600-1800 \mathrm{~mm}$ per year and the average annual temperature is $21-22{ }^{\circ} \mathrm{C}$ (CAVIGLIONE et al., 2000).

\section{Epidemiological questionnaire}

Before the study began, an epidemiological questionnaire was applied to all the properties, to address health management, sex, age, breed, abortion, presence of other animals, and source of water. These questionnaires were filled out through individual interviews in the years 2012 and 2014. On this occasion, an authorization for the use and dissemination of data was obtained from all the producers who participated in this study. This study was approved by the Ethics Committee for Animal Use of the University of the North of Paraná (UNOPAR).

\section{Samples}

The number of samples was calculated by means of the Epi Info software, version 6, using a prevalence of $50 \%$ with $95 \%$ confidence interval. 
Cattle blood samples were obtained in 2012 and 2014, two years apart, and 407 and 331 samples were collected, respectively. Blood samples were taken without anticoagulant and were properly identified. After removal of the clot, the serum was identified and stored at $-20{ }^{\circ} \mathrm{C}$ until the serological tests were performed.

\section{Anti-Neospora caninum antibodies detection}

To detect anti-Neospora caninum antibodies, the indirect fluorescence assay (IFA) was performed in accordance with the technique previously used by Conrad et al. (1993). Animals with titers $\geq 100$ were considered positive (CARDOSO et al., 2012).

\section{Statistical analysis}

The association between seropositive animals and risk variables was investigated using the chisquare test $\left(\mathrm{X}^{2}\right)$ in the Epi Info 6 software, with the statistical significance level taken to be $5 \%$. We calculated the Spearman correlation coefficient through the GraphPad Prism 5.0 software to investigate the relationships involved in the distribution of antibody titers over time.

\section{Results and Discusion}

In the present study, $145(19.7 \%)$ out of the 735 animals sampled were considered positive for anti-N. caninum antibodies: 94/406 (23.1\%) in 2012 and 51/329 (15.5\%) in 2014 (Table 1), which showed statistical differences $(\mathrm{OR}=1.49,1.01<\mathrm{OR}<2.2$, $\mathrm{p}=0.03)$. When the prevalence of farms was studied $68.3(28 / 41)$ and $61 \%$ (25/41) of farms had at least one animal considered as positive in 2012 and 2014, respectively. This variation of antibody levels was observed previuosly by Magalhães et al. (2014) in a longitudinal study with cross-breed dairy cattle from northeast Brazil using IFAT to detect IgG antibodies against $N$. caninum.
The seroprevalence observed in the present study $(23.1 \%)$ are in agreement with the neosporosis seroprevalence from cross-sectional sampling studies on dairy cattle in Paraná state, which has been reported to range from 12 to $33 \%$ (LOCATELLI-DITTRICH et al., 2001; RAGOZO et al., 2003; GUIMARÃES JUNIOR et al., 2004; OGAWA et al., 2005; CAMILLO et al., 2010) and 11.2 to $53.5 \%$ in Brazil (GONDIM et al., 1999; MELO et al., 2001; OGAWA et al., 2005; AGUIAR et al., 2006; MUNHOZ et al., 2006; MELO et al., 2006; MINERVINO et al., 2008; BENETTI et al., 2009; MUNHOZ et al., 2009; TEIXEIRA et al., 2010; BRUHN et al., 2013).

The IFA is the technique most commonly used for anti-N. caninum antibody detection in Brazil, but there is no consensus about which cutoff to use for determining positivity. Thus, a comparison between laboratory techniques could contribute toward evaluating test performance, and towards harmonizing and standardizing protocols (VAN MAANEN et al., 2004).

Serum from 91 animals was tested in both trials (Table 2): among these, 11(12.1\%) showed positivity in 2012 and 10 (11\%) in 2014; 73 (80.2\%) and $3(3.3 \%)$ remained negative and positive, respectively. A total of seven animals (incidence $=$ $7.7 \%$ ) that were negative at the first bleeding became positive at the second one, and eight animals $(8.8 \%$, all of them had more than 30 months) converted from positive to negative for antibodies. Fluctuating of $N$. caninum antibody levels in naturally infected cows have been described previously (CONRAD et al., 1993; MARQUES et al., 2011; MORE et al., 2009; PARE et al., 1996; STENLUND et al., 1999). Thus, Conrad et al. (1993) urged caution when interpreting the serologic results if they are to be used in strategies for the control of neosporosis in cattle. 
Table 1. Outcome of seropositivities for Neospora caninum in dairy cattle from farms of a settlement in 2012 and 2014. Paraná, Brazil.

\begin{tabular}{|c|c|c|c|c|}
\hline \multirow[t]{2}{*}{ Farms } & \multicolumn{2}{|r|}{2012} & \multicolumn{2}{|r|}{2014} \\
\hline & $\mathrm{n}$ & Positives- IFA(\%) & $\mathrm{n}$ & Positives - IFA( $(\%)$ \\
\hline 1 & 7 & $2(28.57)$ & 3 & $2(66.7)$ \\
\hline 2 & 9 & 0 & 8 & $1(12.5)$ \\
\hline 3 & 7 & $1(14.28)$ & 7 & 0 \\
\hline 4 & 21 & $2(9.52)$ & 18 & $2(11.1)$ \\
\hline 5 & 4 & 0 & ND & \\
\hline 6 & 27 & $6(22.22)$ & 5 & $1(20)$ \\
\hline 7 & 45 & $5(11.11)$ & 63 & $10(16)$ \\
\hline 8 & 19 & $3(15.78)$ & 8 & 0 \\
\hline 9 & 16 & $8(50)$ & ND & \\
\hline 10 & 17 & $1(5.8)$ & 5 & 0 \\
\hline 11 & 10 & $1(10)$ & 13 & 0 \\
\hline 12 & 11 & $2(18.18)$ & & \\
\hline 13 & 2 & $1(50)$ & ND & \\
\hline 14 & 25 & $6(24)$ & 14 & $2(14.3)$ \\
\hline 15 & 14 & $9(64.28)$ & 4 & $1(25)$ \\
\hline 16 & 12 & $2(16.66)$ & 14 & $1(7.1)$ \\
\hline 17 & 13 & $2(15.38)$ & 10 & $1(10)$ \\
\hline 18 & 22 & $10(45.45)$ & 15 & $2(13.3)$ \\
\hline 19 & 9 & $1(11.11)$ & ND & \\
\hline 20 & 10 & $4(40)$ & ND & \\
\hline 21 & 14 & $1(7.14)$ & 12 & $4(33.3)$ \\
\hline 22 & 6 & $2(33.33)$ & ND & \\
\hline 23 & 5 & $1(20)$ & ND & \\
\hline 24 & 6 & $1(16.66)$ & 12 & $1(8.3)$ \\
\hline 25 & 12 & $5(41.66)$ & 7 & 0 \\
\hline 26 & 7 & $6(85.71)$ & 11 & $4(57.1)$ \\
\hline 27 & 9 & 0 & 6 & $1(17)$ \\
\hline 28 & 7 & $5(71.42)$ & 7 & $1(14.3)$ \\
\hline 29 & 16 & $3(18.75)$ & ND & \\
\hline 30 & 24 & $4(16.66)$ & ND & \\
\hline 31 & & & 8 & 0 \\
\hline 32 & & & 9 & $3(33.3)$ \\
\hline 33 & & & 2 & $2(100)$ \\
\hline 34 & & & 7 & $2(28.6)$ \\
\hline 35 & & & 10 & $2(20)$ \\
\hline 36 & ND & & 7 & $2(28.6)$ \\
\hline 37 & & & 16 & $3(18.8)$ \\
\hline 38 & & & 9 & $2(22.2)$ \\
\hline 39 & & & 3 & $3(100)$ \\
\hline 40 & & & 7 & $1(14.2)$ \\
\hline 41 & & & 9 & $1(14)$ \\
\hline Total & 406 & $94(23.1)$ & 329 & $51(15.5)$ \\
\hline
\end{tabular}

$\mathrm{ND}=$ Not done. 
Table 2. Seroprevalence of antibodies against Neospora caninum obtained from dairy cattle in 2012 and 2014. Paraná, Brazil.

\begin{tabular}{|c|c|c|c|c|}
\hline Bleed & & Positives & & Titer variation (IFA) \\
\hline $1^{\text {st }}$ year-2012 & 406 & $94(23.1)$ & 100 & 25,600 \\
\hline \multicolumn{5}{|l|}{$2^{\text {nd }}$ year 2014} \\
\hline Re-bleed & $91^{*}$ & $11(12.1)$ & 100 & 800 \\
\hline New cattle & 238 & $40(16.8)$ & 100 & 3,200 \\
\hline Total & 329 & $51(15.5)$ & & \\
\hline
\end{tabular}

\begin{tabular}{cccc}
\hline & \multicolumn{3}{c}{ Serologic background* } \\
\cline { 2 - 3 } & First & Second & \\
& & $73(80.2)$ \\
Neg. & Neg. & $7(7.7)$ \\
Neg. & Pos. & $3(3.3)$ \\
Pos. & Pos. & $8(8.8)$ \\
\hline Pos. & Neg. & $91(100)^{*}$ \\
\hline
\end{tabular}

* Animals that were re-bleed a two years later of the first bleeding.

There is a strong association between seropositivity and abortion among cattle, and high prevalence of anti- $N$. caninum antibodies in the herd increases the risk of abortion at herd level (DUBEY et al., 2007). Corbellini et al. (2002) in Rio Grande do Sul observed that seropositive cows were 3.3 times more likely to abort than seronegative cows. Landmann et al. (2011) in Australia estimated that the risk of miscarriage among seropositive cows was 2.9 to 3.9 times higher than among seronegative cows, and that the likelihood that calves from seropositive mothers might become positive was 3.5 times higher than that of calves from seronegative cows.

In the present study, the variables of age, sex and breed did not show any statistically significant differences in relation to seropositivity (Table 3 ). Melo et al. (2001), in the state of Minas Gerais, did not observe any significant association between the distribution of seropositivity and the ages of the groups, which could be explained by vertical transmission. However, Guimarães Junior et al. (2004) found that age was a risk factor for occurrence of anti-N. caninum antibodies. Munhoz et al. (2009) examined 563 cows on 57 farms in the state of Rio de Janeiro and observed that the Holstein breed was 2.65 times more likely to be seropositive than zebu breeds.

We were unable to correlate the presence of dogs with seropositive cattle, because there was a huge population of dogs in this settlement (approximately six dogs/farm). Among farms in northern Paraná that produced "type B" milk, Guimarães Junior et al. (2004) showed that the presence of seropositive dogs had a correlation with occurrence of anti- $N$. caninum antibodies. 
Table 3. Association between variables and presence of antibodies against Neospora caninum from dairy cattle in 2012 and 2014. Paraná, Brazil.

\begin{tabular}{|c|c|c|c|c|c|c|c|c|c|c|c|c|}
\hline \multirow{2}{*}{$\begin{array}{l}\text { Variables } \\
\text { Age }^{1}\end{array}$} & \multicolumn{4}{|c|}{2012} & \multicolumn{4}{|c|}{2014} & \multicolumn{4}{|c|}{ Total } \\
\hline & $\mathrm{n}$ & $+(\%)$ & $X^{2}$ & $\mathrm{p}$ & $\mathrm{n}$ & $+(\%)$ & \multirow[t]{2}{*}{$\mathrm{X}^{2}$} & \multirow[t]{2}{*}{$\mathrm{p}$} & \multirow{2}{*}{$\begin{array}{r}n \\
160\end{array}$} & \multirow{2}{*}{$\begin{array}{c}+(\%) \\
40(25.0)\end{array}$} & \multirow[t]{2}{*}{$\mathrm{X}^{2}$} & \multirow[t]{2}{*}{$\mathrm{p}$} \\
\hline$\leq 12$ & 150 & $38(25.3)$ & & & 10 & $2(20.0)$ & & & & & & \\
\hline 13 a 24 & 80 & $20(25.0)$ & 1.27 & 0.53 & 21 & $3(14.3)$ & 0.18 & 0.91 & 101 & $23(22.8)$ & 5.1 & 0.08 \\
\hline$\geq 25$ & 176 & $36(20.4)$ & & & 298 & $46(15.5)$ & & & 473 & $82(17.3)$ & & \\
\hline \multicolumn{13}{|l|}{ Sex } \\
\hline Male & 49 & $13(26.5)$ & 0.17 & 0.67 & 34 & $2(5.9)$ & 1.92 & 0.16 & 83 & $15(18.1)$ & 0.07 & 0.8 \\
\hline Female & 357 & $81(22.7)$ & & & 295 & 49 (16.6) & & & 652 & $130(19.9)$ & & \\
\hline \multicolumn{13}{|l|}{ Breed } \\
\hline Jersey & 164 & $33(20.1)$ & & & 120 & $17(14.1)$ & & & 284 & $50(17.6)$ & & \\
\hline Girolando & 90 & $16(17.8)$ & & & 74 & 14 (18.9) & & & 164 & $30(18.3)$ & & \\
\hline Holstein & 25 & $7(28.0)$ & 8.53 & 0.07 & 57 & $10(17.5)$ & 1.82 & 0.77 & 82 & $17(20.7)$ & 5.71 & 0.22 \\
\hline Cross-breeding & 122 & $38(31.1)$ & & & 75 & $10(13.3)$ & & & 197 & $48(24.4)$ & & \\
\hline Others & 5 & $0(0)$ & & & 3 & $0(0)$ & & & 8 & $0(0)$ & & \\
\hline
\end{tabular}

Age is in months.

The highest antibody titer observed in the 1,600 in 2012 and 2014, respectively. This elevated present study was 25,600, in the first trial. However, titers may have been associated with the acute form the majority of the animals showed $100(45 / 145$, of infection, but further studies would need to be $31 \%$, Table 4). Eighteen animals $(19.1 \%, 18 / 94)$ conducted in order to confirm this hypothesis.

and just four animals $(7.8 \%, 4 / 51)$ showed titers $\geq$

Table 4. Titers of antibodies against Neospora caninum obtained by Indirect fluorescence Assay (IFA) from dairy cattle in 2012 and 2014. Paraná, Brazil.

\begin{tabular}{ccccccc}
\hline \multirow{2}{*}{ Titers } & \multicolumn{2}{c}{2012} & \multicolumn{3}{c}{2014} & \multicolumn{3}{c}{ Total } \\
\cline { 2 - 7 } & $\mathrm{n}$ & $\%$ & $\mathrm{n}$ & $\%$ & $\mathrm{n}$ & $\%$ \\
\hline 100 & 33 & 35.1 & 15 & 29.4 & 45 & 31.0 \\
200 & 22 & 23.4 & 14 & 27.4 & 36 & 24.8 \\
400 & 5 & 5.3 & 10 & 19.6 & 15 & 10.3 \\
800 & 16 & 17.0 & 8 & 15.7 & 24 & 16.5 \\
1,600 & 3 & 3.2 & 3 & 5.9 & 6 & 4.1 \\
3,200 & 10 & 10.6 & 1 & 1.9 & 11 & 7.6 \\
6,400 & 2 & 2.13 & 0 & 0 & 2 & 1.4 \\
12,800 & 2 & 2.13 & 0 & 0 & 2 & 1.4 \\
25,600 & 1 & 1.0 & 0 & 0 & 1 & 0.7 \\
\hline Total & 94 & 100 & 51 & 100 & 145 & 100 \\
\hline
\end{tabular}

In summary, we observed a high level of antibodies against $N$. caninum among cattle in this settlement in both years (2012 and 2014). The IFA used here showed good efficacy for epidemiological studies, given that the 91 animals that were retested showed similar prevalences.

\section{Acknowledgment}

J.L. Garcia is recipient of CNPq (Conselho Nacional de Desenvolvimento Científico e Tecnológico) fellowship (grant N. 304083/2015-1). 


\section{References}

AGUIAR, D. M.; CAVALCANTE, G. T.; RODRIGUES, A. A.; LABRUNA, M. B.; CAMARGO, L. M.; CAMARGO, E. P. Prevalence of anti-Neospora caninum antibodies in cattle and dogs from Western mazon, Brazil, in association with some possible risk factors. Veterinary Parasitology, Amsterdam, v. 142, n. 1-2, p. 71-77, 2006.

ANUÁRIO DA PECUÁRIA BRASILEIRA ANUALPEC. Anuário estatístico da pecuária de corte. São Paulo: FNP Consultoria \& Comércio, 2011. 360 p.

BENETTI, A. H.; SCHEIN, F. B.; SANTOS, T. R.; TONIOLlO, G. H.; COSTA, A. J.; MINEO, J. R.; LOBATO, J.; SILVA, D. A. O.; GENNARI, S. M. Pesquisa de anticorpos anti-Neospora caninum em bovinos leiteiros, cães e trabalhadores rurais da região sudoeste do Estado de Mato Grosso. Revista Brasileira de Parasitologia Veterinária, São Paulo, v. 18, n. 1, p. 29-33, 2009.

BRUHN, F.R.P.; DAHER, D. O.; LOPES, E.;BARBIERI, J. M.; ROCHA, C. M. B. M.; GUIMARÃES, A. M. Factors associated with seroprevalence of Neospora caninum in dairy cattle in southeastern Brazil. Tropical Animal Health and Production, Edinburgh, v. 45, n. 5, p. 1093-1098, 2013.

CAMILLO, G.; CADORE, G.; CEZAR, A. S.; TOSCAN, G.; BRÄUNIG, P.; SANGIONI, L. A.; VOGEL, F. S. F. Anticorpos anti-Neospora caninum em bovinos de leite do sudoeste do Estado do Paraná. Arquivo Brasileiro de Medicina Veterinária e Zootecnia, Belo Horizonte, v. 62, n. 6, p. 1511-1513, 2010.

CARDOSO, J. M. S.; AMAKUA, M.; ARAÚJO, A. J. U. S.; GENNARI, S. M. A longitudinal study of Neospora caninum infection on three dairy farms in Brazil. Veterinary Parasitology, Amsterdam, v. 187, n. 3-4, p. 553-557, 2012.

CAVIGLIONE, J. H.; KIIHL, L. R. B.; CARAMORI, P. H.; OlIVEIRA, D. Cartas climáticas do Paraná. Londrina: IAPAR, 2000.

CONRAD, P. A.; BARR, B. C.; SVERLOW, K. W.; ANDERSON, M.; DAFT, B.; KINDE, H.; DUBEY, J. P.; MUNSON, L.; ARDANS, A. In vitro isolation and characterization of a Neospora sp. from aborted bovine fetuses. Parasitology, Glasgow, v. 106, n. 3, p. 239-249, 1993.

CORBELLINI, L. G.; DRIEMEIER, D.; CRUZ, C. F. E.; GONDIN, L. F. P.; WALD, V. Neosporosis as a cause of abortion in dairy cattle in Rio Grande do Sul, southern Brazil. Veterinary Parasitology, Amsterdam, v. 103, n. 3, p. 195-202, 2002.
DUBEY, J. P. Neosporosis in cattle. Veterinary Clinics of North America: Food Animal Practice, Philadelphia, v. 21, n. 2, p. 473-483, 2005.

DUBEY, J. P.; HOLLIS, K.; ROMAND S.; THULLIEZ, P.; KWOK, O. C.; HUNGERFORD, L.; ANCHOR, C.; ETTER, D. High prevalence of antibodies to Neospora caninum in white-tailed deer (Odocoileus virginianus). International Journal for Parasitology, Kidlington, v. 29, n. 10, p. 1709-1711, 1999.

DUBEY, J. P.; SCHARES, G.; ORTEGA-MORA, L. M. Epidemiology and Control of neosporosis and Neospora caninum. Clinical Microbiology Reviews, Washington, v. 20, n. 2, p. 323-367, 2007.

GONDIM, L. F.; SARTOR, I. F.; MONTEIRO, L. A.; HARITANI, M. Neospora caninum infection in an aborted bovine foetus in Brazil. New Zealand Veterinary Journal, Wellington, v. 47, n. 1, p. 35, 1999.

GUIMARÃES JUNIOR, J. S.; SOUZA, S. L. P.; BERGAMASCHI, D. P.; GENNARI, S. M. Prevalence of Neospora caninum antibodies and factors associeted with their presence in dairy cattle of the north of Paraná state. Brazil. Veterinary Parasitology, Amsterdam, v. 124, n. 1-2, p. 1-8, 2004.

INSTITUTO BRASILEIRO DE GEOGRAFIA E ESTATÍSTICA-IBGE. Estatística da Produção Pecuária. Brasilia: IBGE, 2012.

LANDMANN, J. K.; GUNN, A. A.; O'DONOGHUE, P. J.; TRANTER, W. P.; MCGOWAN, M. R. Epidemiology and impact of Neospora caninum infection in three Queensland tropical dairy cattle. Reproduction in Domestic Animals, Malden, v. 46, n. 4, p. 734-737, 2011.

LOCATELLI-DITTRICH, R.; SOCCOL, V. T.; RICHARTZ, R. R.; GASINO-JOINEAU, M. E.; VINNE, R.; PINCKNEY, R. D. Serological diagnosis of neosporosis in a dairy herd of dairy cattle in southern Brazil. The Journal of Parasitology, Lawrence, v. 87, n. 6, p. 1493-1494, 2001.

MARQUES, F. A.; HEADLEY, A. S.; FIGUEREDOPEREIRA, V.; TARODA, A.; BARROS, L. D.; CUNHA, I. A.; MUNHOZ, K.; BUGNI, F. M.; ZULPO, D. L.; IGARASHI, M.; VIDOTTO, O.; GUIMARAES JÚNIOR, J. S.; GARCIA, J. L. Neospora caninum: evaluation of vertical transmission in slaughtered beef cows (Bos indicus). Parasitology Research, New York, v. 108, n. 4, p. 1015-1019, 2011.

MELO, C. B.; LEITE, R. C.; SOUZA, G. N. Frequência de infecção por Neospora caninum em dois diferentes sistemas de produção de leite e fatores predisponentes à 
infecção em bovinos em Minas Gerais. Revista Brasileira de Parasitologia Veterinária, São Paulo, v. 10, n. 2, p. 67-74, 2001.

MELO, D. P. G.; SILVA, A. C. da; ORTEGA-MORA, L. M.; BOAVANTURA, C. M. Prevalência de anticorpos anti- Neospora caninum em bovinos das microrregiões de Goiânia e Anápolis, Goiás. Revista Brasileira de Parasitologia Veterinária, São Paulo, v. 15, n. 3, p. 105109, 2006.

MINERVINO, A. H.; RAGOZO, A. M.; MONTEIRO, R. M.; ORTOLANI, E. L.; GENNARI, S. M. Prevalence of Neospora caninum antibodies in cattle from Santarém, Pará, Brazil. Research in Veterinary Science, Kidlington, v. 84, n. 2, p. 254-256, 2008.

MORE, G.; BACIGALUPE, D.; BASSO, W.; RAMBEAUD, M.; BELTRAME, F.; RAMIREZ, B.; VENTURINI, M. C.; VENTURINI, L. Frequency of horizontal and vertical transmission for Sarcocystis cruzi and Neospora caninum in dairy cattle. Veterinary Parasitology, Amsterdam, v. 160, n. 1-2, p. 51-54, 2009.

MUNHOZ; A. D.; FLAUSINO, W.; SILVA, R. T.; ALMEIDA, C. R.; LOPES, C. W. Distribution of anti-Neospora caninum antibodies in dairy cows at municipalities of Resende and Rio Claro in the State of Rio de Janeiro, Brazil. Revista Brasileira de Parasitologia Veterinária, São Paulo, v. 15, n. 3, p. 101-104, 2006.

MUNHOZ, A. P.; PEREIRA, M. J. S.; FLAUSINO, W.; LOPES, C. W. G. Neospora caninum seropositivity in cattle breeds in the south fluminense Paraíba Valley, state of Rio de Janeiro. Pesquisa Veterinária Brasileira, Seropédica, v. 29, n. 1, p. 29-32, 2009.

OGAWA, L.; FREIRE, R. L.; VIDOTTO, O.; GONDIM, L. F. P.; NAVARRO, I. T. Occurrence of antibodies to Neospora caninum and Toxoplasma gondii in dairy cattle from the northern region of the Paraná State, Brazil. Arquivo Brasileiro de Medicina Veterinária e Zootecnia, Belo Horizonte, v. 57, n. 3, p. 312-316, 2005.
PARE, J.; THURMOND, M. C.; HIETALA, S. K. Congenital Neospora caninum infection in dairy cattle and associated calfhood mortality. Canadian Veterinary Journal, Ottawa, v. 60, n. 2, p. 133-139, 1996.

RAGOZO, A. M. A.; PAULA, V. S. O.; SOUZA, S. L. P.; BERGAMASCHI, D. P.; GENNARI, S. M. Ocorrência de anticorpos anti-Neospora caninum em soros bovinos procedentes de seis estados Brasileiros. Revista Brasileira de Parasitologia Veterinária, São Paulo, v. 12, n. 1, p. 33-37, 2003.

RITTA NETO, A. S. Análise da conjuntura agropecuária - agrometeorologia - Safra 2010/11 - PARANÁ. Curitiba: SEAB/DERAL, 2010. 11 p.

STENLUND, S.; KINDAHL, H.; MAGNUSSON, U.; UGGLA, A.; BJORKMA, C. Serum antibody profile and reproductive performance during two consecutive pregnancies of cows naturally infected with Neospora caninum. Veterinary Parasitology, Amsterdam, v. 85, n. 4, p. 227-234, 1999.

TEIXEIRA, W. C.; UZÊDA, R. S.; GONDIM, L. F. P.; SILVA, M. I. S.; PEREIRA, H. M.; ALVES, L. C.; FAUSTINO, M. A. G. Prevalência de anticorpos antiNeospora caninum (Apicomplexa: Sarcocystidae) em bovinos leiteiros de propriedades rurais de três microrregiões no estado do Maranhão. Pesquisa Veterinária Brasileira, Seropédica, v. 30, n. 9, p. 729734, 2010.

VAN MAANEN, C.; WOUDA, W.; SCHARES, G.; VON BLUMRÖDER, D.; CONRATHS, F. J.; NORTON, R.; WILLIAMS，D. J.; ESTEBAN-REDONDO, I.; INNES, E. A.; MATTSSON, J. G.; BJÖRKMAN, C.; FERNÁNDEZ-GARCÍA， A.; ORTEGA-MORA， L. M.; MÜLLER, N.; SAGER, H.; HEMPHILL, A. An interlaboratory comparison of immunohistochemistry and PCR methods for detection of Neospora caninum in bovine foetal tissues. Veterinary Parasitology, Amsterdam, v. 126, n. 4, p. 351-364, 2004. 